\title{
Bartonella birtlesii sp. nov., isolated from small mammals (Apodemus spp.)
}

\author{
Delphine Bermond, ${ }^{1}$ Rémy Heller, ${ }^{1}$ Francine Barrat, ${ }^{2}$ Gilles Delacour, ${ }^{3}$ \\ Christoph Dehio, ${ }^{4}$ Annie Alliot, ${ }^{2}$ Henri Monteil, ${ }^{1}$ Bruno Chomel, ${ }^{5}$ \\ Henri-Jean Boulouis ${ }^{2}$ and Yves Piémont ${ }^{1}$
}

Author for correspondence: Delphine Bermond. Tel: +33 3882119 70. Fax: +33 388251113 . e-mail: delphine.bermond@medecine.u-strasbg.fr

\footnotetext{
1 Institut de Bactériologie de la Faculté de Médecine, Université Louis Pasteur, Hôpitaux Universitaires de Strasbourg, 3 rue Koeberlé, 67000 Strasbourg, France

\begin{abstract}
Three strains isolated from Apodemus spp. were similar to Bartonella species on the basis of phenotypic characteristics. Futhermore, genotypic analysis based on sequence analysis of the 16S rRNA and gltA genes and on DNA-DNA hybridization showed that the three isolates represented a distinct and new species of Bartonella. The name Bartonella birtlesii is proposed for the new species. The type strain of B. birtlesii sp. nov. is IBS $325^{\top}\left(=\right.$ CIP $_{106294^{\top}}=$ CCUG 44360').
\end{abstract}

Keywords: Bartonella birtlesii, rodents, taxonomy, citrate synthase, 16S rDNA gene

\section{INTRODUCTION}

Prior to 1993, Bartonella bacilliformis was the only member of the Bartonella genus. Now, after only a few years of research and taxonomic study, this genus includes 12 approved species available in the international bacterial collections (Brenner et al., 1993). For two species [B. bacilliformis (Weinman, 1968) and Bartonella quintana (Vinson \& Fuller, 1961)] the human is the natural host, for three others [Bartonella henselae (Regnery et al., 1992; Welch et al., 1992), Bartonella clarridgeiae (Lawson \& Collins, 1996) and Bartonella koehlerae (Droz et al., 1999)] it is the cat (Felis domesticus) and for one other (Bartonella alsatica; Heller et al., 1999) it is the rabbit (Oryctolagus cuniculus). For five Bartonella species, small mammals are the hosts: the rat (Rattus rattus) is the host for Bartonella tribocorum (Heller et al., 1998), Microtus

The GenBank/EMBLDDBJ accession numbers for the 165 rRNA gene sequence and the partial $3^{\prime}$-end gene sequence of strain IBS $325^{\top}$ ( = CIP $106294^{\top}=$ CCUG 44360 $)$ are AF204274 and AF204272, respectively. pennsylvanicus is the host for Bartonella vinsonii (Baker, 1946), Apodemus spp. are the hosts for Bartonella taylorii (Birtles et al., 1995), Clethrionomys glareolus is the host for Bartonella grahamii (Birtles et al., 1995) and Microtus agrestis is the host for Bartonella doshiae (Birtles et al., 1995). Furthermore, B. taylorii, $B$. grahamii and $B$. doshiae are able to infect numerous species of small woodland mammals and there is no narrow animal host spectrum of infection. The 12th approved species is Bartonella elizabethae (Daly et al., 1993), for which only a single isolate, originating from a human case of endocarditis, was described. The $16 \mathrm{~S}$ rRNA gene sequence of this species is close to that of the rat Bartonella sp., B. tribocorum (Heller et al., 1998) and to that of other isolates not yet validly described, but all were isolated from small wild mammals (Birtles \& Raoult, 1996; Kosoy et al., 1997). In addition to these 12 species, two others have been described in Peromyscus spp. [Bartonella peromysci (Birtles et al., 1995; Ristic \& Kreier, 1984)] and in the mole [Bartonella talpae (Birtles et al., 1995; Ristic $\&$ Kreier, 1984)], but type strains for these species are no longer extant. Moreover, B. vinsonii (Baker, 1946; 
Breitschwerdt et al., 1995), now includes three subspecies, one of which, $B$. vinsonii subsp. arupensis, was isolated from humans and mice (Peromyscus leucopus) and is therefore presumptively considered as pathogenic for humans (Welch et al., 1999; Hofmeister et al., 1998).

Thus, several Bartonella species have been isolated from numerous small mammals. For one species that is potentially pathogenic for humans (B. elizabethae) small woodland mammals are suspected as a reservoir; B. vinsonii subsp. arupensis (Welch et al., 1999), however, was isolated from mice and humans. B. grahamii DNA was detected from the anterior chamber fluid of the eye in an HIV-negative woman who presented with bilateral eye inflammatory disease. This detection was performed by using PCR amplification and sequence analysis of the 16S rRNA gene (Kerkhoff et al., 1999). Thus, the members of the bacterial genus Bartonella, particularly species isolated from small woodland mammals, appear to be a group of emerging human pathogens. Better knowledge of the bacteria harboured by wild small mammals is therefore necessary.

The aim of this work was to characterize a new Bartonella group, members of which were isolated in France and the UK from the blood of small mammals belonging to the genus Apodemus.

\section{METHODS}

Animals, blood sampling and culture conditions. Small mammals were caught in February 1997 by a professional trapper in a wetland conservation area (at point kilometre PK 275, from the Bodensee in Germany), near the River Rhine, in Gerstheim, France. Identification of the small mammals was based on morphology and dentition. Animals were anaesthetized by diethylether inhalation and then $0.2 \mathrm{ml}$ blood was collected from each animal by intracardiac puncture. Blood was transferred to a paediatric lysis-centrifugation tube (Wampole Laboratories). After centrifugation, the pellet was plated onto Columbia-base agar plates containing $5 \%$ fresh, defibrinated rabbit blood. The plates were incubated at $35^{\circ} \mathrm{C}$ in a moist atmosphere containing $5 \% \mathrm{CO}_{2}$ for 4 weeks.

Bacterial strains. Two isolates obtained from Apodemus spp. and named IBS $325^{\mathrm{T}}$ and IBS 358 were examined. (We were unable to identify the Apodemus spp. precisely, because the animals captured were too young.) In addition, strain N40, kindly provided by R. Birtles (Bristol, UK) and isolated in the UK from Apodemus sylvaticus, was included in the study.

Reference strains used for DNA-DNA hybridization. $B$. elizabethae ATCC $49927^{\mathrm{T}}$, B. henselae ATCC $49882^{\mathrm{T}}$ and $B$. quintana ATCC VR-358 ${ }^{\mathrm{T}}$ were purchased from the American Type Culture Collection (ATCC; Manassas, VA, USA). $B$. alsatica CIP $105477^{\mathrm{T}}$ and B. tribocorum CIP $105476^{\mathrm{T}}$ were kindly provided by R. Heller (Strasbourg, France). $B$. koehlerae ATCC $700693^{\mathrm{T}}$ was kindly given by B. B. Chomel (Davis, CA, USA). B. doshiae NCTC $12862^{\mathrm{T}}$, B. grahamii NCTC $12860^{\mathrm{T}}$, B. taylorii NCTC $12861^{\mathrm{T}}$ and B. vinsonii ATCC VR- $152^{\mathrm{T}}$ were kindly provided by R. Birtles (Bristol, UK). B. clarridgeiae ATCC $51734^{\mathrm{T}}$ was kindly given by $\mathbf{J}$. Clarridge (Houston, TX, USA).
Electron microscopy. Bacteria were grown on solid medium and submitted to electron microscopy as described previously (Fusseneger et al., 1996). Briefly, bacteria were suspended in PBS $(0.145 \mathrm{M} \mathrm{NaCl}, 0.15 \mathrm{M}$ sodium phosphate), spread onto a water surface, absorbed onto Formvar-coated nickel grids, stained in $1 \%(\mathrm{w} / \mathrm{v})$ uranyl acetate and then air-dried. Samples were examined with a JEOL 100CX2 electron microscope.

Biochemical analysis. The following biochemical assays were performed with diagnostic tablets (Rosco Diagnostica): the Voges-Proskauer reaction, tributyrine hydrolysis and pyrazinamidase, proline aminopeptidase and trypsin-like activities. Pre-formed bacterial enzyme activity was tested using the MicroScan Rapid Anaerobe Panel (Dade International) according to the manufacturer's instructions and as described previously (Welch et al., 1993; Birtles et al., 1995).

Amplification of 16S rRNA and citrate synthase genes. DNA was extracted from bacterial suspensions via the Chelex extraction technique (De Lamballerie, 1992). An approximately $1500 \mathrm{bp}$ fragment of the $16 \mathrm{~S}$ rRNA gene was amplified from the extracted DNA by using the eubacterial universal primers specific for the $16 \mathrm{~S} \mathrm{rRNA}$ gene, i.e. primer P8 (5'-AGAGATTTGATCCTGGCTCAG-3') and primer Pc1544(5'-AAGGAGGTGATCCAGCCGCA-3')(Heller et al., 1998). PCR amplification of the citrate synthase gene was performed, as described by Birtles \& Raoult (1996), with two primers, i.e. primer CS.140f (5'-TTACTTATGATCCKGGYTTTA-3', where K represents equimolar amounts of $\mathrm{G}$ and $\mathrm{T}$ and $\mathrm{Y}$ represents equimolar amounts of $\mathrm{C}$ and $\mathrm{T}$ ) and primer BhCS.1137n (5'-AATGCAAAAAGAACAGTAAACA-3'). Standard procedures for preventing sample DNA cross-contamination were undertaken (Kwok \& Higuchi, 1989). Each set of reactions also included negative controls to confirm the absence of cross-contamination between samples and previously amplified DNA or field samples. The presence of the desired amplicons was controlled by electrophoresis on a $1.5 \%$ agarose gel, followed by ethidium bromide staining and visualization on a UV transilluminator.

Purification of the amplicons and DNA sequencing. The amplified fragments were purified via phenol extraction and 2-propanol precipitation (Brow, 1990). Sequencing of the complete 16S rRNA gene was performed on the coding and complementary strands by using the following four primer pairs 5'-labelled with FITC (Eurogentec): P8 and Pc535 (5'GTATTACCGCGGCTGCTGGCAC-3');P515(5'-GTGCCAGCAGCCGCGGTAAKAC-3') and Pc804 (5'-GACTACCAGGGTATCTAATCC-3'); P784(5'-GGATTAGATACCCTGGTAGTC-3') and Pc1198 (5'-ACTTGACGTTATCCCCACCTTCC-3'); and P1174 (5'-GAGGAAGGTGGGGATGACGTC-3') and Pc1544.

Partial sequencing of the 3 '-end of the citrate synthase gene ( $g l t A)$ was performed on coding and complementary strands by using primer pairs BhCS.1137n and BhCS.781p (5'GGGGACCAGCTCATGGTGG-3'). All primers were 5'labelled with fluorescein isothiocyanate.

The sequencing reaction was performed by using a Thermo Sequenase Fluorescent Labelled Primer Cycle Sequencing kit with 7-deaza-dGTP (Amersham), according to the manufacturer's instructions. The sequences were obtained with an ALF DNA Sequencer (Pharmacia Biotech) used according to the manufacturer's instructions.

Sequence analysis. The DNA sequences obtained were 
compared with those from other Bartonella spp. and other bacteria, contained in the EMBL/GenBank database. The sequences were aligned by using the CLUSTAL method (Higgins \& Sharp, 1988) with DNASTAR software.

Nucleotide sequence accession numbers. The EMBL/ GenBank accession numbers for the 16S rRNA sequences used for the sequence comparison given are as follows: B. alsatica, AJ002139; B. bacilliformis, M65249; B. clarridgeiae, X8920; B. doshiae, Z31351; B. elizabethae, L01260; B. grahamii, Z31349; B. henselae Houston-1, M73229; B. henselae BA-TF, Z11684; B. koehlerae, AF76237; B. quintana Fuller, M11927; B. taylorii, Z31350; B. tribocorum, AJ003070; B. vinsonii, L01259; B. vinsonii subsp. berkhoffii, L35052; B. vinsonii subsp. arupensis, U71322; B. vinsonii Baker, Z31352; Escherichia coli, Z46753; Afipia felis, M65248, Brucella abortus, AF091354; Agrobacterium tumefaciens, M11223; Rickettsia prowazekii, M21789; Rickettsia rickettsii, M21293; Bartonella strain C7-rat, Z70004; Bartonella strain C5-rat, Z0008; Bartonella strain C4-phy, Z70007; Bartonella strain C1-phy, Z70006; Bartonella strain R-phy2, Z70001; Bartonella strain R-phy1, Z70005; and Bartonella strain N40, Z7002.

The EMBL/GenBank accession numbers for the citrate synthase gene sequences used for sequence comparisons, as given by Birtles \& Raoult (1996), are as follows: B. bacilliformis LA6.3, Z70021; B. clarridgeiae, U84386; B. doshiae, Z70017; B. elizabethae, Z70009; B. grahamii, Z70016; Bartonella henselae, L38987; B. quintana Fuller, Z70014; B. taylorii, Z70013; B. tribocorum, AJ005494; B. vinsonii, Z70015; B. vinsonii subsp. berkhoffii, U28075; Bartonella strain C7-rat, Z70020; Bartonella strain C5-rat, Z70018; Bartonella strain C4-phy, Z70019; Bartonella strain C1-phy, Z70022; Bartonella strain R-phy2, Z70011; Bartonella strain R-phy1, Z70010; and Bartonella strain N40, Z70012.

The EMBL/GenBank accession numbers for the citrate synthase gene sequences of Bartonella spp., as given by Kosoy et al. (1997), are as follows: strain A1, U84372; strain A2, U84373; strain A3, U84374; strain B1, U84375; strain B2, U84376; strain C1, U84377; strain C2, U84378; strain D1, U84379; strain D2, U84380; strain D3, U84381; strain D4, U84382; strain D5, U84383; strain D6, U84384; strain D7, U84385.

The EMBL/GenBank accession number for the citrate synthase gene sequences of $B$. vinsonii subsp. arupensis (Welch et al., 1999) and B. alsatica (Heller et al., 1999) are U77057 and AF204273, respectively.

DNA-DNA hybrization. DNA extraction and purification were performed as described previously (Riegel et al., 1994). DNA hybridizations between the labelled DNA and the unlabelled fragmented DNA were performed at $58^{\circ} \mathrm{C}$ for $16 \mathrm{~h}$ in $0.42 \mathrm{M} \mathrm{NaCl}$ by using the nuclease trichloroacetic acid method as described earlier (Grimont et al., 1980; Riegel et al., 1994).

Determination of DNA base composition. The $\mathrm{G}+\mathrm{C}$ content of DNA was determined by using the capillary electrophoresis method as described previously (Riegel et al., 1995).

\section{RESULTS}

Among the 28 Bartonella strains isolated from the 34 small mammals, two (IBS $325^{\mathrm{T}}$ and IBS 358) were isolated from two Apodemus spp. and had exactly the same 16S rRNA gene and glt $A$ sequences (Table 1). These sequences were identical to those of strain N40, which was also isolated from an Apodemus species. The 16S rRNA gene sequences of 26 other strains isolated from the other wild mammals were different and so these strains were not included in this study.

\section{Phenotypic characteristics}

The three strains produced homogeneous, rough, round, grey-white colonies, $0.6-1.0 \mathrm{~mm}$ in diameter, that were slightly adherent to the surface of the culture medium. Bacterial suspension in PBS was not homogeneous because of bacterial aggregation. Gramstaining revealed short, slender, straight or slighly curved Gram-negative bacilli. Electron microscopy examination with negative staining showed small bacilli that lacked flagella. They were catalase and oxidase-negative, gave a negative Voges-Proskauer reaction, had no urease activity and did not produce acid from trehalose. They hydrolysed bis- $p$-nitrophenyl phosphate but not $N$-acetyl $\beta$-D-glucosaminide. They had amino acid arylamidase activity with the following amino acids: arginine, lysine (alkaline as well as acid), glycine, leucine, methionine, proline and tryptophan. The strains had trypsin-like activity and glycylglycylarylamidase activity but no pyrrolidonylarylamidase activity. These data were identical for the three strains tested; only the results obtained with strain IBS $325^{\mathrm{T}}$ are given in Table 2 .

\section{$16 S$ rRNA gene sequence analysis}

The length of the 16S rRNA gene sequenced was 1394 bp (all located within the 16S rRNA gene). We sequenced the amplicon obtained with the eubacterial universal primers P8 and Pc1544.

Strains IBS $325^{\mathrm{T}}$, IBS 358 and Bartonella isolate N40 had an identical 16S rRNA gene sequence, which differed from that of the 12 other Bartonella species contained in the EMBL/GenBank database. The percentage similarities are presented in Table 1.

The species with the closest 16S rRNA gene sequence was $B$. taylorii $(99 \cdot 3 \%$ similarity). The most distant $16 \mathrm{~S}$ rRNA gene sequences within the genus Bartonella were those of B. clarridgeiae and B. bacilliformis $(97 \cdot 0$ and $97 \cdot 2 \%$ similarity, respectively).

When bacterial genera close to Bartonella were studied, the $16 \mathrm{~S}$ rRNA gene sequence of strain IBS $325^{\mathrm{T}}$ was found to be $93.8 \%$ similar to that of B. abortus and $91.4 \%$ similar to that of $A$. tumefaciens.

\section{Citrate synthase gene sequence analysis}

The partial sequence of $320 \mathrm{bp}$ in the $3^{\prime}$-end of the citrate synthase gene was identical for the three strains, but differed from the corresponding sequences of all 
Table 1. DNA-DNA hybridization rate and $16 \mathrm{~S}$ rRNA gene and gltA similarity between the Bartonella species and the strain IBS $325^{\top}$

- , Not tested.

\begin{tabular}{|c|c|c|c|c|c|c|}
\hline \multirow{2}{*}{ Bartonella strain } & \multirow{2}{*}{$\begin{array}{l}\text { Mean hybridization } \\
(\%) \text { with strain } \\
\text { IBS } 325^{\mathrm{T}} \text { of } \\
\text { (trial } 1 \text { and } \\
\text { trial } 2)^{*}\end{array}$} & \multirow{2}{*}{$\begin{array}{c}\text { Hybridization } \\
\text { with strain IBS } \\
3^{\mathrm{T}}(\%)\end{array}$} & \multicolumn{2}{|c|}{ Similarity (\%) } & \multirow{2}{*}{$\begin{array}{c}\text { Actual base } \\
\text { differences } \\
\text { (16S rRNA gene) }\end{array}$} & \multirow{2}{*}{$\begin{array}{c}G+C \\
\text { content } \\
(\mathrm{mol} \%)\end{array}$} \\
\hline & & & $\begin{array}{c}320 \text { bp of } 3^{\prime} \\
\text { end (glt } A \text { gene) }\end{array}$ & $\begin{array}{c}1394 \text { bp of } \\
\text { 16S rRNA gene }\end{array}$ & & \\
\hline Strain IBS $325^{\mathrm{T}}$ & $(100 / 100)$ & 100 & 100 & 100 & 0 & 38 \\
\hline Strain IBS 358 & $(92 / 96)$ & 94 & 100 & 100 & 0 & 38 \\
\hline Strain N40 & $(94 / 95)$ & 95 & 100 & 100 & 0 & $38 \dagger$ \\
\hline B. alsatica CIP $105477^{\mathrm{T}}$ & $(28 / 27)$ & 27 & $92 \cdot 5$ & $98 \cdot 8$ & 8 & $37 \dagger$ \\
\hline $\begin{array}{l}\text { B. bacilliformis } \\
\text { ATCC } 35685^{\mathrm{T}}\end{array}$ & - & - & $84 \cdot 5$ & $97 \cdot 2$ & 19 & - \\
\hline $\begin{array}{l}\text { B. clarridgeiae } \\
{\text { ATCC } 51734^{\mathrm{T}}}^{\text {ATC }}\end{array}$ & - & - & $85 \cdot 6$ & $97 \cdot 0$ & 25 & - \\
\hline B. doshiae NCTC $12862^{\mathrm{T}}$ & $(27 / 32)$ & 28 & $88 \cdot 4$ & $98 \cdot 5$ & 7 & $41 \S$ \\
\hline B. elizabethae ATCC $49927^{\mathrm{T}}$ & $(17 / 21)$ & 18 & $87 \cdot 7$ & $97 \cdot 9$ & 11 & $41 \|$ \\
\hline B. grahamii NCTC $12860^{\mathrm{T}}$ & $(22 / 24)$ & 22 & $89 \cdot 6$ & $98 \cdot 8$ & 6 & $40 \S$ \\
\hline B. henselae ATCC $49882^{\mathrm{T}}$ & $(21 / 20)$ & 21 & $90 \cdot 6$ & $97 \cdot 5$ & 15 & $41 \|$ \\
\hline B. koehlerae ATCC $700693^{\mathrm{T}}$ & $(24 / 27)$ & 25 & $90 \cdot 9$ & $98 \cdot 3$ & 10 & - \\
\hline B. quintana ATCC VR-358 & $(28 / 31)$ & 29 & $87 \cdot 4$ & $98 \cdot 1$ & 14 & $40 \|$ \\
\hline B. taylorii $\mathrm{NCTC} 12861^{\mathrm{T}}$ & $(23 / 27)$ & 25 & $90 \cdot 6$ & $99 \cdot 3$ & 3 & $41 \S$ \\
\hline B. tribocorum CIP $105476^{\mathrm{T}}$ & $(22 / 23)$ & 23 & $90 \cdot 6$ & $98 \cdot 5$ & 8 & $38 \uparrow$ \\
\hline \multicolumn{7}{|l|}{ B. vinsonii subsp. vinsonii } \\
\hline ATCC VR- $152^{\mathrm{T}}$ & $(27 / 33)$ & 30 & $90 \cdot 9$ & $98 \cdot 8$ & 6 & $41 \|$ \\
\hline $\begin{array}{l}\text { B. vinsonii subsp. arupensis } \\
\text { ATCC } 700727^{\mathrm{T}}\end{array}$ & - & - & $90 \cdot 8$ & $98 \cdot 8$ & 6 & $41 \#$ \\
\hline Strain C1-phy & - & - & $87 \cdot 1$ & $99 \cdot 0$ & 5 & - \\
\hline Strain C4-phy & - & - & $87 \cdot 7$ & $98 \cdot 8$ & 6 & - \\
\hline Strain R-phy1 & - & - & $88 \cdot 4$ & $99 \cdot 1$ & 4 & - \\
\hline Strain R-phy2 & - & - & $87 \cdot 7$ & $99 \cdot 0$ & 5 & - \\
\hline Strain A1 & - & - & $89 \cdot 3$ & - & - & - \\
\hline Strain A2 & - & - & $88 \cdot 4$ & - & - & - \\
\hline Strain A3 & - & - & $88 \cdot 4$ & - & - & - \\
\hline Strain B1 & - & - & $91 \cdot 2$ & - & - & - \\
\hline Strain B2 & - & - & $91 \cdot 8$ & - & - & - \\
\hline Strain D7 & - & - & $90 \cdot 6$ & - & - & - \\
\hline
\end{tabular}

* Mean of data from trial $1 /$ trial 2.

$\dagger$ Birtles \& Raoult (1996).

+ Heller et al. (1999).

$\S$ Birtles et al. (1995).

\| Daly et al. (1993).

- Heller et al. (1998).

\# Welch et al. (1999).

type strains of Bartonella species available in the EMBL/GenBank database.

The closest glt $A$ sequences were those of $B$. alsatica (92.5\% similarity) isolated from wild rabbits (Heller et al., 1999) and Bartonella strain B2 $(91.8 \%)$ isolated from a small rodent (Kosoy et al., 1997). All of the results are presented in Table 1. All other $3^{\prime}$-end citrate synthase gene sequences available in the EMBL/ GenBank database shared less than $91.2 \%$ similarity.

\section{DNA-DNA hybridizations}

DNA of the strain IBS $325^{\mathrm{T}}$ was labelled and hybridized with unlabelled DNA of isolate N40, isolate IBS 358 , isolate 325 and of the type strains of B. alsatica, 
Table 2. Differential phenotypic characteristics of the isolate IBS $325^{\top}$ when compared with those of type strains of the Bartonella species tested

Taxa (with references): 1 , IBS $325^{\mathrm{T}} ; 2$, B. alsatica $^{7} ; 3$, B. bacilliformis $^{1,2,8} ; 4$, B. clarridgeiae $^{2} ; 5$, B. doshiae $^{1} ; 6$, B. elizabethae $^{3,9} ; 7$,

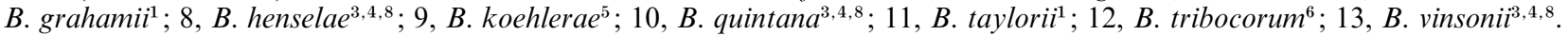

References: 1, Birtles et al. (1995); 2, Clarridge et al. (1995); 3, Daly et al. (1993); 4, Drancourt \& Raoult (1993); 5, Droz et al. (1999); 6, Heller et al. (1998); 7, Heller et al. (1999); 8, Welch et al. (1993); 9, Welch et al. (1999). All species were positive for hydrolysis of arginine, glycine and leucine. The characteristic of Gram-staining was omitted. +, Positive; -, negative; NT, not tested; v, variable; w, weakly positive.

\begin{tabular}{|c|c|c|c|c|c|c|c|c|c|c|c|c|c|}
\hline \multirow[t]{2}{*}{ Characteristic } & \multicolumn{13}{|c|}{ Taxa: } \\
\hline & 1 & 2 & 3 & 4 & 5 & 6 & 7 & 8 & 9 & 10 & 11 & 12 & 13 \\
\hline Oxidase & - & - & - & - & - & - & - & - & - & $\mathrm{v}$ & - & - & $\mathrm{V}$ \\
\hline Catalase & - & - & + & - & - & - & - & - & - & - & - & - & - \\
\hline Haemolysis & - & - & - & - & - & + & - & - & - & - & - & - & - \\
\hline Motility & - & - & + & + & - & - & - & - & - & - & - & - & - \\
\hline Urea & - & - & - & - & NT & - & NT & - & NT & - & NT & - & - \\
\hline Voges-Proskauer & - & - & NT & NT & + & NT & + & - & - & + & + & - & - \\
\hline Glycylglycine & + & + & NT & NT & + & NT & + & NT & + & NT & + & + & + \\
\hline Lysine (alkaline) & + & + & NT & NT & + & + & + & + & + & + & + & + & $\mathrm{V}$ \\
\hline Lysine (acidic) & + & + & + & NT & + & $\mathrm{W}$ & + & + & - & - & + & + & $\mathrm{V}$ \\
\hline Methionine & + & + & NT & + & + & NT & + & + & + & NT & + & + & NT \\
\hline Proline & + & + & - & + & - & + & + & + & - & + & + & - & $\mathrm{V}$ \\
\hline Tryptophan & + & + & NT & + & + & + & + & + & + & + & + & + & + \\
\hline
\end{tabular}

B. doshiae, B. elizabethae, B. grahamii, B. henselae, $B$. koehlerae, B. quintana, B. taylorii, B. tribocorum and $B$. vinsonii. IBS $325^{\mathrm{T}}$ showed less than $30 \%$ relatedness with all type strains of Bartonella species tested, but showed more than $94 \%$ relatedness with DNA from IBS 358 and DNA from N40.

\section{DISCUSSION}

Strains IBS $325^{\mathrm{T}}$, IBS 358 and Bartonella isolate N40 exhibited phenotypic characteristics similar to those of other Bartonella species: they grew slowly $(10 \mathrm{~d}$ for primary isolation and $6 \mathrm{~d}$ for subcultures), required $\mathrm{CO}_{2}$ and produced small colonies on Columbia-blood agar plates. Futhermore, they were negative for oxidase, catalase and the Voges-Proskauer reaction. They did not hydrolyse trehalose. They had amino acid arylamidase activity with arginine, lysine, glycine, leucine, methionine, proline and tryptophan and had a trypsin-like activity.

Additional data were obtained from genetic analysis. The three isolates had exactly the same sequence for the 16S rRNA gene. All of them belonged to the Bartonella genus, since this sequence showed 97.099.3 \% similarity to those of other Bartonella species; this is within the range of similarity found between the type strains of other Bartonella species (97.5-99.3\% ; Birtles \& Raoult, 1996). The closest 16S rRNA gene sequences were those of $B$. taylorii, $B$. vinsonii and $B$. vinsonii subsp. arupensis and those of strains C1-phy, C4-phy, R1-phy and R2-phy (Birtles \& Raoult, 1996), all of which had been isolated from small woodland mammals (Fig. 1).

Furthermore, the three isolates IBS $325^{\mathrm{T}}$, IBS 358 and N40 showed a unique 3'-end citrate synthase sequence. The level of sequence similarity between IBS $325^{\mathrm{T}}$ and the previously described Bartonella species was in the range $84.5-92.5 \%$. This range was similar to those previously described for the type strains of Bartonella species [83.8-93.2\% (Birtles \& Raoult, 1996) and $88 \cdot 7-96 \cdot 4 \%$ (Kosoy et al., 1997)]. These data, together with the 16S rRNA gene sequence (Table 1), the culture characteristics (colonial morphology, duration of bacterial growth, microscopic appearance of the bacteria after Gram-staining) and the isolation of the bacteria from the blood of Apodemus spp., all support the classification of these three isolates within the genus Bartonella.

On the basis of DNA-DNA hybridization, the three isolates IBS $325^{\mathrm{T}}$, IBS 358 and N40 belong to the same species, since they showed more than $94.0 \%$ hybridization to each other. Futhermore, the DNA of strains N40 and IBS $325^{\mathrm{T}}$ showed 95 and $97 \%$ hybridization, respectively, with the labelled DNA of strain IBS 358 (data not shown). Conversely, the DNA of strains IBS 358 and N40 showed 94 and 95\% relatedness, respectively, with the labelled DNA of strain IBS $325^{\mathrm{T}}$. Moreover, all of the type strains of Bartonella species tested showed DNA relatedness to strain IBS $325^{\mathrm{T}}$ of less than $30 \%$ (Table 1). These data indicated that the three isolates belong to a single Bartonella species distinct from all those previously described, according 


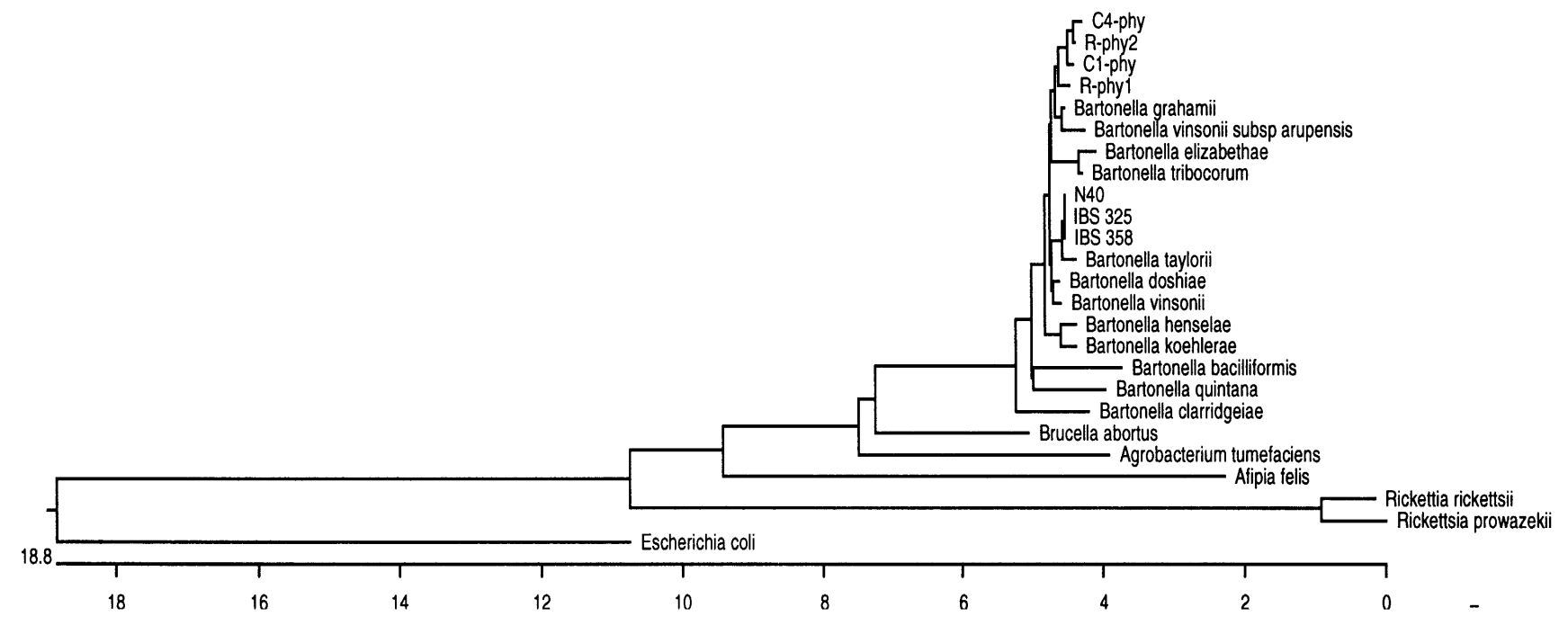

Fig. 1. Phylogenetic tree derived from a $1394 \mathrm{bp}$ fragment of the $16 \mathrm{~S}$ gene for the Bartonella strains and other representatives of the Eubacteria. This phylogenetic tree was constructed using the CLUSTAL method with DNASTAR software. The lengths of the horizontal lines are significant. The length of each pair of branches represents the distance between sequence pairs. The scale beneath the tree measures the distance between sequences. Units indicate the number of substitution events.

to previously established criteria (Stackebrandt \& Goebel, 1994).

In spite of the fact that the three isolates of the new Bartonella species were isolated from wild Apodemus spp., this animal genus should not be regarded as a specific host, since we used IBS $325^{\mathrm{T}}$ to inoculate outbred and inbred laboratory mice and found that they developed long-term bacteraemia (unpublished data). The ability of this new species to infect humans should be assessed, since other rodent-associated Bartonella spp. associated with human diseases have been described, namely B. grahamii (Kerkhoff et al., 1999) and B. vinsonii subsp. arupensis (Hofmeister et al., 1998; Welch et al., 1999).

To detect possible cases of human infection by Bartonella birtlesii, serological and genetic tools specific for $B$. birtlesii should be established.

\section{Description of Bartonella birtlesii sp. nov.}

Bartonella birtlesii (birt.les'i.i. M.L. gen. n. birtlesii of Richard J. Birtles, whose studies have contributed to an improved understanding of the taxonomy of the Bartonella genus).

Colonies grown on blood agar appeared homogeneous, rough, round and grey-white. Electron microscopic examination showed small bacilli without flagella. Primary culture of strain $B$. birtlesii was obtained after $10 \mathrm{~d}$ incubation at $35^{\circ} \mathrm{C}$ in a moist atmosphere containing $5 \% \mathrm{CO}_{2}$. Subculture on agar was obtained after $6 \mathrm{~d}$ culture in the same conditions. The three strains tested were all oxidase-negative and catalasenegative, had negative Voges-Proskauer reactions, showed no urease activity and were unable to hy- drolyse trehalose or $N$-acetyl $\beta$-D-glucosaminide. They all hydrolysed bis- $p$-nitrophenyl phosphate and had amino acid arylamidase activity with the following amino acids: arginine, lysine (alkaline as well as acid), glycine, leucine, methionine, proline and tryptophan. The new species showed a trypsin-like activity and a glycylglycylarylamidase activity but no pyrrolidonylarylamidase activity. The new species was distinguished from the other Bartonella species by its $16 \mathrm{~S}$ rRNA gene sequence and by whole-DNA hybridization. The type strain is IBS $325^{\mathrm{T}}$ (isolated from the blood of an Apodemus sp.) and is deposited in the Collection de l'Institut Pasteur, Paris, France (CIP $106294^{\mathrm{T}}=$ CCUG $44360^{\mathrm{T}}$ ).

\section{ACKNOWLEDGEMENTS}

We thank Richard Birtles for having kindly provided strain N40. We are also grateful to F. Lamarque, from the Office Nationale de la Chasse, who gave us the authorization to catch small wild mammals. We also thank P. Riegel for helpful discussions.

\section{REFERENCES}

Baker, J. A. (1946). A rickettsial infection of canadian voles. $J$ Exp Med 84, 37-50.

Birtles, R. J. \& Raoult, D. (1996). Comparison of partial citrate synthase gene $(\mathrm{glt} A)$ sequences for phylogenetic analysis of Bartonella species. Int J Syst Bacteriol 46, 891-897.

Birtles, R. J., Harrison, T. G., Saunders, N. A. \& Molyneux, D. H. (1995). Proposals to unify the genera Grahamella and Bartonella, with descriptions of Bartonella talpae comb. nov., Bartonella peromysci comb. nov., and three new species, Bartonella grahamii sp. nov., Bartonella taylorii sp. nov., and Bartonella doshiae sp. nov. Int J Syst Bacteriol 45, 1-8. 
Breitschwerdt, E. B., Kordick, D. L., Malarkey, D. E., Keene, B., Hadfield, T. L. \& Wilson, K. (1995). Endocarditis in a dog due to infection with a novel Bartonella subspecies. J Clin Microbiol 33, 154-160.

Brenner, D. J., O'Connor, S. P., Winkler, H. H. \& Steigerwalt, A. G. (1993). Proposals to unify the genera Bartonella and Rochalimaea, with descriptions of Bartonella quintana comb. nov., Bartonella vinsonii comb. nov., Bartonella henselae comb. nov., and Bartonella elizabethae comb. nov., and to remove the family Bartonellaceae from the order Rickettsiales. Int J Syst Bacteriol 43, 777-786.

Brow, M. A. (1990). Sequencing with Taq DNA polymerase. In PCR Protocols: a Guide to Methods and Applications, pp. 189-196. Edited by M. A. Innis, D. H. Gelfand, J. J. Sninsky \& T. J. White. San Diego, CA: Academic Press.

Clarridge, J. E. R., Raich, T. J., Pirwani, D. \& 7 other authors (1995). Strategy to detect and identify Bartonella species in routine clinical laboratory yields Bartonella henselae from human immunodeficiency virus-positive patient and unique Bartonella strain from his cat. J Clin Microbiol 33, 2107-2113.

Daly, J. S., Worthington, M. G., Brenner, D. J. \& 7 other authors. (1993). Rochalimaea elizabethae sp. nov. isolated from a patient with endocarditis. J Clin Microbiol 31, 872-881.

De Lamballerie, X., Zandotti, X., Vignoli, C., Bollet, C. \& DeMicco, P. (1992). A one-step microbial DNA extraction method using "Chelex 100" suitable for gene amplification. Res Microbiol 143, 785-790.

Drancourt, M. \& Raoult, D. (1993). Proposed tests for the routine identification of Rochalimaea species. Eur J Clin Microbiol Infect Dis 12, 710-713.

Droz, S., Chi, B., Horn, E., Steigerwalt, A. G., Whitney, A. M. \& Brenner, D. J. (1999). Bartonella koehlerae sp. nov., isolated from cats. J Clin Microbiol 37, 1117-1122.

Fusseneger, M., Kahrs, A. F., Facius, D. \& Meyer, T. F. (1996). Tetrapac (tcp), a novel genotype of Neisseria gonorrhoeae affecting epithelial cell invasion, natural transformation competence and cell separation. Mol Microbiol 19, 1357-1372.

Grimont, P. A. D., Popoff, M. Y., Grimont, F., Coynault, C. \& Lemelin, M. (1980). Reproducibility and correlation study of three deoxyribonucleic acid hybridization procedures. Curr Microbiol 4, 325-330.

Heller, R., Riegel, P., Hansmann, Y. \& 7 other authors (1998). Bartonella tribocorum sp. nov., a new Bartonella species isolated from the blood of wild rats. Int J Syst Bacteriol 48, 1333-1339.

Heller, R., Kubina, M., Mariet, P. \& 9 other authors (1999). Bartonella alsatica sp. nov., a new Bartonella species isolated from the blood of wild rabbits. Int J Syst Bacteriol 49, 283-288.

Higgins, D. G. \& Sharp, P. M. (1988). CLUSTAL: a package for performing multiple sequence aligment on a microcomputer. Gene 73, 237-244.

Hofmeister, E. K., Kolbert, C. P., Abdulkarim, A. S. \& 7 other authors (1998). Cosegregation of a novel Bartonella species with Borrelia burgdorferi and Babesia microti in Peromyscus leucopus. J Infect Dis 177, 409-416.
Kerkhoff, F. T., Bergmans, A. M., van Der Zee, A. \& Rothova, A. (1999). Demonstration of Bartonella grahamii DNA in ocular fluids of a patient with neuroretinitis. J Clin Microbiol 37, 4034-4038.

Kosoy, M. Y., Regnery, R. L., Tzianabos, T., Marston, E. L., Jones, D. C., Green, D., Maupin, G. O., Olson, J. G. \& Childs, J. E. (1997). Distribution, diversity, and host specificity of Bartonella in rodents from the Southeastern United States. Am J Trop Med Hyg 57, 578-588.

Kwok, S. \& Higuchi, R. (1989). Avoiding false positives with PCR. Nature 339, 237-238.

Lawson, P. A. \& Collins, M. D. (1996). Description of Bartonella clarridgeiae sp. nov., isolated from the cat of a patient with Bartonella henselae septicemia. Med Microbiol Lett 5, 64-73.

Regnery, R. L., Anderson, B. E., Clarridge, J. E., Rodriguez Barradas, M. C., Jones, D. C. \& Carr, J. H. (1992). Characterization of a novel Rochalimaea species, $R$. henselae sp. nov., isolated from blood of a febrile, human immunodeficiency virus-positive patient. J Clin Microbiol 30, 265-274.

Riegel, P., de Briel, D., Prévost, G., Jehl, F. \& Monteil, H. (1994). Genomic diversity among Corynebacterium jeikeium strains and comparison with biochemical characteristics and antimicrobial susceptibilities. J Clin Microbiol 32, 1860-1865.

Riegel, P., Ruimy, R., de Briel, D., Prévost, G., Jehl, F., Christen, R. \& Monteil, H. (1995). Corynebacterium seminale sp. nov. a species associated with genital infections in male patients. J Clin Microbiol 32, 2244-2249.

Ristic, M. \& Kreier, J. P. (1984). Familly II. Bartonellaceae Gieszczykiewick (sic) 1939, 25 $5^{\mathrm{AL}}$. In Bergey's Manual of Systematic Bacteriology, pp. 717-718. Edited by N. R. Krieg \& J. G. Holt. Baltimore: Williams \& Wilkins.

Stackebrandt, E. \& Goebel, B. M. (1994). Taxonomic note: a place for DNA-DNA reassociation and $16 \mathrm{~S}$ rRNA sequence analysis in the present definition in bacteriology. Int $J$ Syst Bacteriol 44, 846-849.

Vinson, J. W. \& Fuller, H. S. (1961). Studies on trench fever. I. Propagation of Rickettsia-like microorganisms from a patient's blood. Pathol Microbiol 24, S152-S166.

Weinman, D. R. (1968). Bartonellosis. In Infectious Blood Diseases of Man and Animals, pp. 3-24. Edited by D. R. Weinman \& M. Ristic. New York: Academic Press.

Welch, D. F., Pickett, D. A., Slater, L. N., Steigerwalt, A. G. \& Brenner, D. J. (1992). Rochalimaea henselae sp. nov., a cause of septicemia, bacillary angiomatosis, and parenchymal bacillary peliosis. J Clin Microbiol 30, 275-280.

Welch, D. F., Hensel, D. M., Pickett, D. A., San Joaquin, V. H., Robinson, A. \& Slater, L. N. (1993). Bacteremia due to Rochalimaea henselae in a child: practical identification of isolates in the clinical laboratory. J Clin Microbiol 31, 2381-2386.

Welch, D. F., Carroll, K. C., Hofmeister, E. K., Persing, D. H., Robison, D. A., Steigerwalt, A. G. \& Brenner, D. J. (1999). Isolation of a new subspecies, Bartonella vinsonii subsp. arupensis, from a cattle rancher: identity with isolates found in conjunction with Borrelia burgdorferi and Babesia microti among naturally infected mice. J Clin Microbiol 37, 2598-2601. 